\title{
Nitrous oxide prediction in manure from pigs given mustard $x$ grapeseed oil cakes as a replacement for sunflower meal
}

\author{
Mihaela Hăbeanu ${ }^{1 *}$, Nicoleta Aurelia Lefter ${ }^{1}$, Smaranda Mariana \\ Toma1, Lavinia Idriceanu1, Anca Gheorghe1, Ioan Surdu² \\ *corresponding author: mihaela.habeanu@ibna.ro
}

\begin{abstract}
${ }^{1}$ National Research and Development Institute for Animal Biology and Nutrition, Laboratory of Animal Nutrition, Balotesti, Calea Bucuresti no. 1, 077015, Ilfov, Romania. ${ }^{2}$ Mountain Economy Centre (Ce-Mont), Romanian Academy/ "Costin C. Kiritescu" National Institute of Economic Researches, Bucharest, 050711, Romania
\end{abstract}

\section{ABSTRACT}

During the last century, the emission of nitrous oxide $\left(\mathrm{N}_{2} \mathrm{O}\right)$ from the livestock sector increased significantly. $\mathrm{N}_{2} \mathrm{O}$ is a greenhouse gas with 298-fold higher global warming potential (GWP) than $\mathrm{CO}_{2}$. Pigs accounted for about $26 \%$ of $\mathrm{N}_{2} \mathrm{O}$ emissions. The formation of $\mathrm{N}_{2} \mathrm{O}$ occurs through nitrification and denitrification processes in manure. This study aimed to estimate $\mathrm{N}_{2} \mathrm{O}$ production in the manure of growing-finishing pigs by using our experimental data in the model. The associative effects of dietary mustard and grapeseed oil cakes (MxG), as an alternative for sunflower meal (SFM), on performance and efficiency traits were also determined. Forty growing-finishing pigs were randomly allocated in two groups ( 2 replicates per group) fed two diets: $\mathrm{C}$ diet (based on SFM, $15 w t$ ) and E diet (based on M and G mixture, 7:8wt:wt). Our model includes as initial input data: body weight (BW), feed intake, nitrogen intake, dietary dry matter, and fibre intake. Using literature prediction equations, including total nitrogen output (TNO) as the main parameter, we established $\mathrm{N}_{2} \mathrm{O}$ production expressed as equivalent $\mathrm{CO}_{2}$ (E-CO2). A decline with $3 \%$ for $\mathrm{BW}(\mathrm{P}=0.44)$, respectively $9.0 \%$ for average daily gain (ADG, $\mathrm{P}=0.21$ ) in pigs given $\mathrm{MxG}$ was recorded. Correlated with growth parameters, efficiency traits (feed intake, feed: gain ratio, $\mathrm{N}$ and fibre intake) were decreased as well $(\mathrm{P}>0.05)$. Dietary addition of MxG led to a 5\% lower level of $\mathrm{N}_{2} \mathrm{O}$ production in manure. The reduction of TNO was not significant $(<7.14 \%$ in the $\mathrm{E}$ diet compared to the $\mathrm{C}$ diet). In our trial, a relatively low $\mathrm{N}$ intake percentage is retained in the pigs body $35.56 \%$ in the $C$ group and $35.98 \%$ in the $\mathrm{E}$ group, $\mathrm{P}>0.05$ ). Based on these results, we conclude that the inclusion of $15 \% \mathrm{MxG}$ mixture in pigs diets, although slightly declining growth parameters, 
is a valuable nutritional solution by their contribution to lowering $\mathrm{N}_{2} \mathrm{O}$ and $\mathrm{N}$ output in the manure.

Keywords: pigs, grapeseed cake, mustard cake, sunflower meal, $\mathrm{N}_{2} \mathrm{O}$, nitrogen

\section{INTRODUCTION}

A diversity of interventions can be applied in livestock, including those that target to mitigate animal emissions. Feeding management is accepted as one of the most important tools to alleviate greenhouse gases (GHGs) production. Although many solutions to mitigate GHGs were implemented, a further step consists of using new practices to cover the knowledge gaps. The European Commission sets out the new growth strategy "for a growth that gives back more than it takes away" that covers all sectors of the economy, including the livestock sector. It highlights the importance of promoting efficient ways of using resources by redirecting to a circular economy, a clean environment, and reaching climate neutrality, restoring biodiversity and cutting pollution.

During the last century, the emission of GHGs from the livestock sector increased significantly. However, several studies considered the agricultural sector to have the capability to mitigate GHGs (Philippe and Nicks, 2014; Grossi et al., 2018; Lenerts et al., 2019; Castrillón et al., 2020; Habeanu et al., 2020). In the livestock sector, the GHGs represent losses of energy, nitrogen and organic matter $(\mathrm{OM})$. The main type of GHGs from the livestock sector are $\mathrm{CH}_{4}(25 \%), \mathrm{CO}_{2}$ (32\%, from land use) and $\mathrm{N}_{2} \mathrm{O}$ (31\% from manure (Moran and Wall, 2011). Grossi et al. (2018) show that manure storage contributes 0.71 GT, which means $10 \%$ of the total GHGs emission.

$\mathrm{CO}_{2}$ is the gas used as a reference, such as the GWP value is 1 . The accumulation of $\mathrm{CO}_{2}, \mathrm{~N}_{2} \mathrm{O}$ and $\mathrm{CH}_{4}$ are a cause of GWP, although, in livestock, the E-CO2 does not contribute to GWP. $\mathrm{N}_{2} \mathrm{O}$ has 298 -fold higher GWP than $\mathrm{CO}_{2}$ $\left(\mathrm{Eq}-\mathrm{CO}_{2}\right)$.

Pigs accounted for about $26 \%$ of $\mathrm{N}_{2} \mathrm{O}$ emissions. The synthesis of manure $\mathrm{N}_{2} \mathrm{O}$ by-products occurs through nitrification and denitrification processes in anaerobic conditions and/or accumulation of nitrite. Oxygen favours $\mathrm{N}_{2} \mathrm{O}$ accumulation (Philippe and Nick, 2014).

In one respect, animal husbandry is an important source of protein. Statistics show an increase in global consumption of animal products. But on the other hand, animals' husbandry also means pollution, although the impact is not major. The gaseous pollution generated by pig farms may be due to the decomposition of manure. That has implications for the atmosphere and the health of farmers and their neighbours. The European Parliament's resolution on a strategy for the long-term reduction of EU GHGs emissions under the Paris Agreement (2019/2582, RSP) states that net emissions must be reduced 
close to zero in all sectors of the economy, which should contribute to joint efforts to reduce emissions. In this context, it becomes imperative to identify and valorise, at maximum potential, new or lesser-known alternative resources.

The question raised was how to contribute to reducing pollution in pig husbandry beyond the aspects already known and applied. Using by-products as production residues could lead to favourable outcomes in feed costs and the environment.

The purpose of this paper consists of using three by-products from oil industry mustard cakes x grapeseed cakes (MxG) and sunflower meal (SFM), respectively, to predict $\mathrm{N}_{2} \mathrm{O}$ production in the manure of growing-finishing pigs. The associative effects of dietary MxG as an alternative for SFM on nitrogen $(\mathrm{N})$ metabolism, performance and efficiency traits were also determined.

\section{MATERIALS AND METHODS}

The bioassay was done at IBNA Balotesti according to 7976/12/2020 protocol approved by the Ethical Committee of the IBNA Balotesti.

\section{Experimental setup}

Forty growing-finishing TOPIGS pigs [sows Large White $\times$ Hybrid (Large White $\times$ Pietrain) and boar Talent, mainly Duroc], $56 \pm 3$ days old, with an initial body weight of $21 \mathrm{~kg} \pm 3$, were randomly allocated in two groups (2 replicates per group) given two diets: $\mathrm{C}$ diet (based on SFM, 15\%) and $\mathrm{E}$ diet (based on MxG mixture, 7\%+8\%, Table 1).

The feed was provided twice as daily meals, and feed intake and leftovers were registered daily. In our diet, the association of M with G cakes was established to be $7 \%$ respectively $8 \%$ to ensure the pigs' nutritional requirements were at a similar level while fibre and their component had higher content.

The diets and by-product fibre composition were calculated using EvaPig ${ }^{\circledR}$ software, version 2.0.3.2 (2020) developed by the French National Institute for Agricultural Research (Table 2).

The animals were individually weighed with an electronic scale on the 56 and 94 days after farrowing.

The gross chemical composition was determined by standardised methods according to Commission Regulation (EC) no. 152 (2009). The byproducts (M and $\mathrm{G}$ cakes) were procured from 2E-Prod SRL. 
Table 1. Compound feed formula (as-fed basis)

\begin{tabular}{|c|c|c|}
\hline Ingredients (\%) & C diet & E diet \\
\hline Maise & 53.91 & 53.91 \\
\hline Rice bran & 15 & 15 \\
\hline Soybean meal & 13 & 13 \\
\hline Mustard cake & - & 7 \\
\hline Grapeseed cake & - & 8 \\
\hline Sunflower meal & 15 & - \\
\hline Corn gluten feed & - & - \\
\hline Milk powder & - & - \\
\hline L-Lysine-HCl & 0.09 & 0.09 \\
\hline DL-Methionine & - & - \\
\hline Calcium carbonate & 1.64 & 1.64 \\
\hline Monocalcium phosphate & 0.15 & 0.15 \\
\hline Salt & 0.1 & 0.1 \\
\hline Choline premix & 0.1 & 0.1 \\
\hline Phytase & 0.01 & 0.01 \\
\hline Vitamin and trace mineral mixture & 1.0 & 1.0 \\
\hline \multicolumn{3}{|c|}{ Calculated chemical composition ( $\mathrm{g} \mathrm{x} \mathrm{Kg}$ feed ${ }^{-1}$ ) } \\
\hline $\mathrm{ME} \mathrm{MJ/Kg}$ & 12.49 & 12.43 \\
\hline $\mathrm{CP}$ & 158.7 & 153.6 \\
\hline EE & 30.3 & 39.2 \\
\hline Crude fibre & 63.00 & 72.70 \\
\hline Lys & 10.5 & 10.5 \\
\hline Lys d & 8.9 & 8.1 \\
\hline Met + Cys & 6.6 & 6.6 \\
\hline Met +Cys d & 5.7 & 5.7 \\
\hline $\mathrm{Ca}$ & 8.1 & 8.1 \\
\hline $\mathrm{Pd}$ & 2.0 & 2.0 \\
\hline Cellulose & 52.5 & 59.3 \\
\hline
\end{tabular}

Abbreviation: DM dry matter, ME metabolisable energy, CP crude protein, EE ether extract, Lys lysine, Met + Cys. Methionine + cysteine, Ca calcium, P phosphorus, d digestible.

*The vitamin-mineral premix ( $\mathrm{kg}$ feed $^{-1}$ ): $6000 \mathrm{IU}$ vitamin A; $800 \mathrm{IU}$ vitamin $\mathrm{D} 3 ; 20 \mathrm{IU}$ vitamin E; $1 \mathrm{mg}$ vitamin $\mathrm{K} 3$; $1 \mathrm{mg}$ vitamin B1; $3.04 \mathrm{mg}$ vitamin B2; $10 \mathrm{mg}$ vitamin B3; $6.3 \mathrm{mg}$ vitamin $\mathrm{B}$; $1.5 \mathrm{mg}$ vitamin B6; $0.03 \mathrm{mg}$ vitamin B7; $0.3 \mathrm{mg}$ vitamin B9; $0.02 \mathrm{mg}$ vitamin B12; $30 \mathrm{mg} \mathrm{Mn} ; 80$ $\mathrm{mg} \mathrm{Fe} ; 25 \mathrm{mg} \mathrm{Cu} ; 100 \mathrm{mg} \mathrm{Zn;} 0.22 \mathrm{mg} \mathrm{I} ; 0.22 \mathrm{mg} \mathrm{Se} ; 0.3 \mathrm{mg} \mathrm{Co} ; 60 \mathrm{mg}$ antioxidant.

The diets had similar content in energy, protein and limiting amino acids. 
Table 2. Diets and by-products fibre and their fractions composition

\begin{tabular}{lccccc}
\hline \multicolumn{1}{c}{ Ingredients (\%)* } & C diet & E diet & $\begin{array}{c}\text { Mustard } \\
\text { cakes }\end{array}$ & $\begin{array}{c}\text { Grapeseed } \\
\text { cakes }\end{array}$ & $\begin{array}{c}\text { Sunflower } \\
\text { meal }\end{array}$ \\
\hline Fibre & 6.30 & 7.27 & 11.42 & 41.86 & 25.49 \\
NDF & 15.67 & 18.85 & 33.28 & 77.78 & 51.31 \\
ADF & 7.42 & 10.6 & 21.61 & 69.13 & 39.33 \\
ADL & 2.17 & 4.67 & 9.58 & 45.97 & 10.02 \\
Cellulose & 5.25 & 5.93 & 12.03 & 23.16 & 29.31 \\
Hemicellulose & 8.25 & 8.25 & 11.67 & 8.65 & 11.80 \\
\hline
\end{tabular}

Abbreviation: neutral-detergent fiber (NDF), acid-detergent fiber (ADF), lignin (ADL).

\section{$\mathrm{N}$ - Balance and $\mathrm{N}_{2} \mathrm{O}$ production calculation}

To predict the $\mathrm{N}$ metabolism parameters and concentration of $\mathrm{N}_{2} \mathrm{O}$, we developed a model that was included as initial input data: body weight (BW), feed intake, nitrogen intake, dietary dry matter, and fibre intake. For urinary and faeces, $\mathrm{N}$ calculation the Joergensen et al. (2013) equations based on $\mathrm{N}$, protein and dry matter intake were used. Using literature prediction equations, including total nitrogen output (TNO) as main parameters, calculated the $\mathrm{N}_{2} \mathrm{O}$ production expressed as $\mathrm{Eq}^{-} \mathrm{CO}_{2}$. The indicators evaluated are described in figure 1.

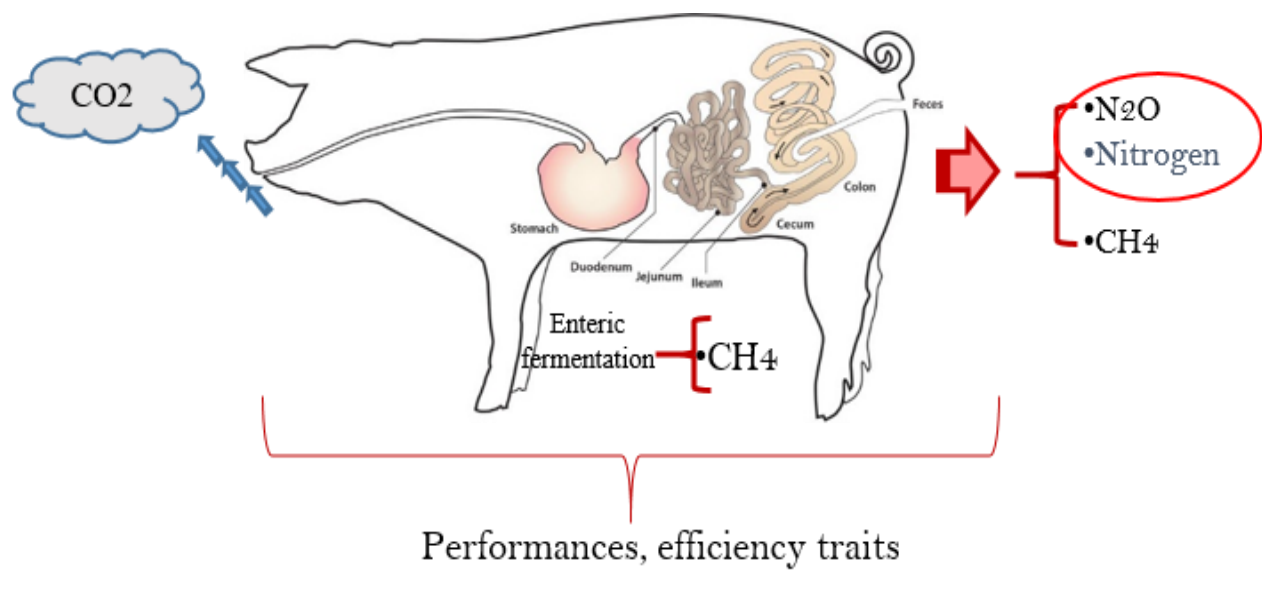

Figure 1. Adapted from Rational Livestock Nutrition In Rural Areas. Chapter 3. Animal Feeding Systems in Europe (Dragomir, Habeanu, Gheorghe, 2016).

Statistical analysis

Data were analysed using of Software Statistical Package SPSS (2011). Shapiro-Wilk test was used to determine data distribution. The fixed factor 
in the model was diet. Significant differences were considered at a P-value $\leq 0.05$.

\section{RESULTS AND DISCUSSION}

\section{Growth parameters}

Figures 2 and 3 show the effect of the MxG mixture on BW and ADG compared to SFM. No significant differences were noticed irrespective of the parameters assessed. However, a slight decline was observed on pigs fed $\mathrm{E}$ diet, respective final BW smaller with 3\%, and ADG smaller with $9 \%$ compared to animals given SFM.

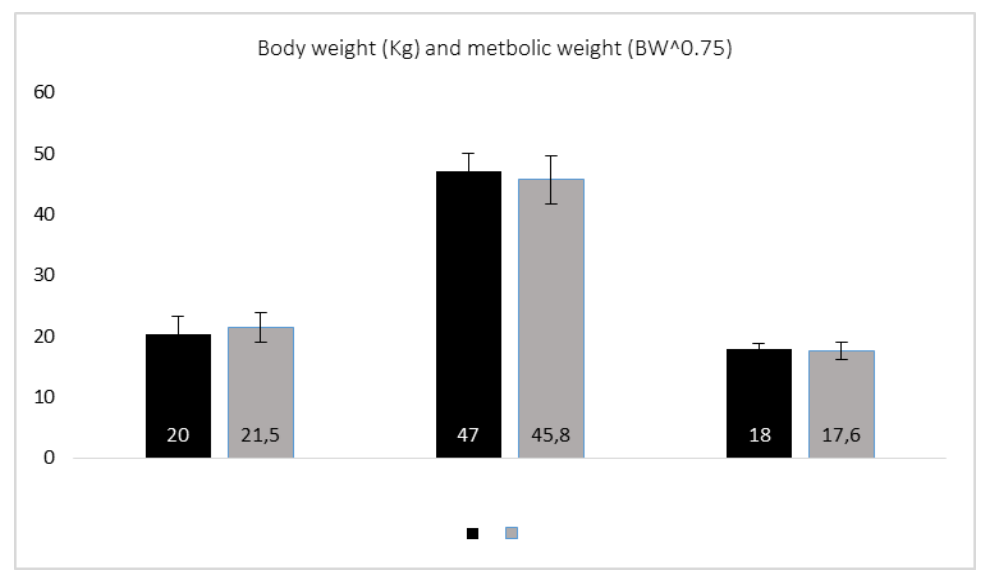

Figure 2. Pigs live weight and metabolic body weight

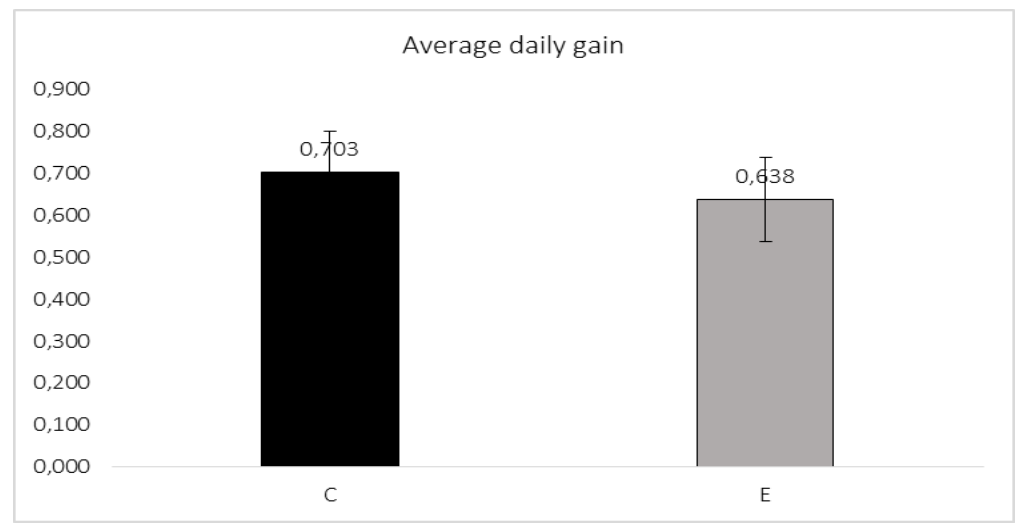

Figure 3. Average daily gain

Correlated with the growth parameters, the efficiency characteristics decreased in the MxG fed group, respective feed consumption $<3.5 \%$ and feed conversion ratio $<10.7 \%$. 
Nitrogen balance and $\mathrm{N}_{2} \mathrm{O}$ estimation

GHGs are gaseous compounds that capture longwave radiation emitted from Earth's and re-send it to the Earth(www.britannica.com/science/ greenhouse-gas).

Figure 4 shows the GHG cycle in pigs' farms. $\mathrm{CO}_{2}$ emissions from manure management are considered biogenetic and are neglected when analysing total GHGs emissions. The Intergovernmental Panel on Climate Change (IPCC, 2016, 2019) states that $\mathrm{CO}_{2}$ emissions from manure management are zero because plants reuse it through photosynthesis.

According to the IPCC (2019), improved agricultural practices and forestrelated mitigation activities can significantly contribute to removing $\mathrm{CO} 2$ from the atmosphere at a relatively low cost. The idea consists of stabilisation of the $\mathrm{C}$ in such a way as to avoid an atmospheric alert.

An alarm signal was issued when the emission of $\mathrm{N}_{2} \mathrm{O}$ from the livestock sector increased significantly. $\mathrm{N}_{2} \mathrm{O}$ is a GHG with 298-fold higher global warming potential than $\mathrm{CO}_{2}\left(\mathrm{Eq}-\mathrm{CO}_{2}\right)$. Pigs accounted for about $26 \%$ of $\mathrm{N}_{2} \mathrm{O}$ emissions. The formation of $\mathrm{N}_{2} \mathrm{O}$ occurs through nitrification and denitrification processes in manure.

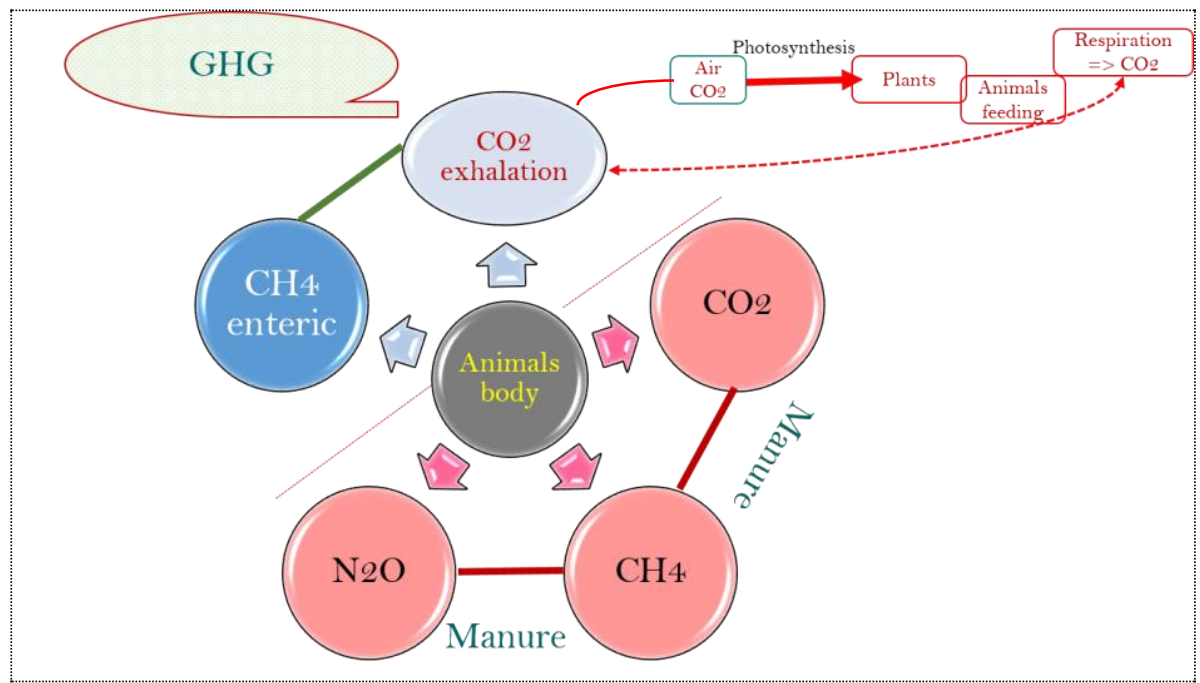

Figure 4. GHGs cycle for pigs.

Nitrogen is an important component of the dietary protein involved in many metabolic processes but is one of the most expensive nutrients. It was highlighted that $32-46 \%$ of $\mathrm{N}$ consumed is retained by pigs (Dourmad et al., 2017; Millet et al., 2018, Hăbeanu et al., 2020). 2/3 of nutrients released are N (Millet et al., 2018). 
The feed represents one way to minimise the level of $\mathrm{N}$ excreted (Monteiro et al., 2010; Dourmad et al., 2017; Wang and al., 2018). In the traditional diets for pigs, the farmers used SFM associated with soybean meal. Using by-products as production residues could lead to favourable outcomes in feed costs and the environment. Our premise was that $M$ and $G$ residues delivered by the oil industry could replace SFM due to their nutritional composition. The $\mathrm{N}$ intake was $5 \%$ lower in the $\mathrm{E}$ diet (figure 5). Consequently, the concentration of $\mathrm{N}$ retained was $4.3 \%$ lower in the $\mathrm{E}$ diet than the classical diet based on SFM (figure 6). A relatively low $\mathrm{N}$ intake percentage was retained in the pigs body $(35.56 \%$ in the $C$ group and $35.98 \%$ in the E group, $\mathrm{P}>0.05$ ).

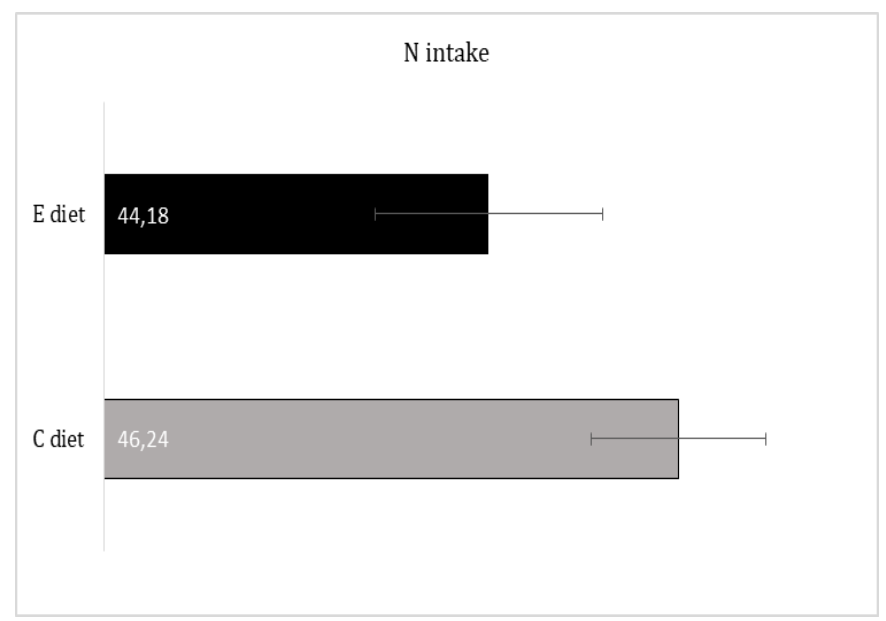

Figure 5. $\mathrm{N}$ consumed by pigs fed differently

It is important to estimate, especially $\mathrm{TNO}$, since this is the main parameter used to assess the $\mathrm{N}_{2} \mathrm{O}$. In our study, TNO was $7.14 \%$ lower in animals fed MxG mixture. The possible explanation consists of dietary higher concentration of fibre components in diets with MxG mixture addition. Fibre is considered an essential nutrient for pig feeding, involved in many physiological processes and producing gases (Jarrett and Ashworth, 2018). 


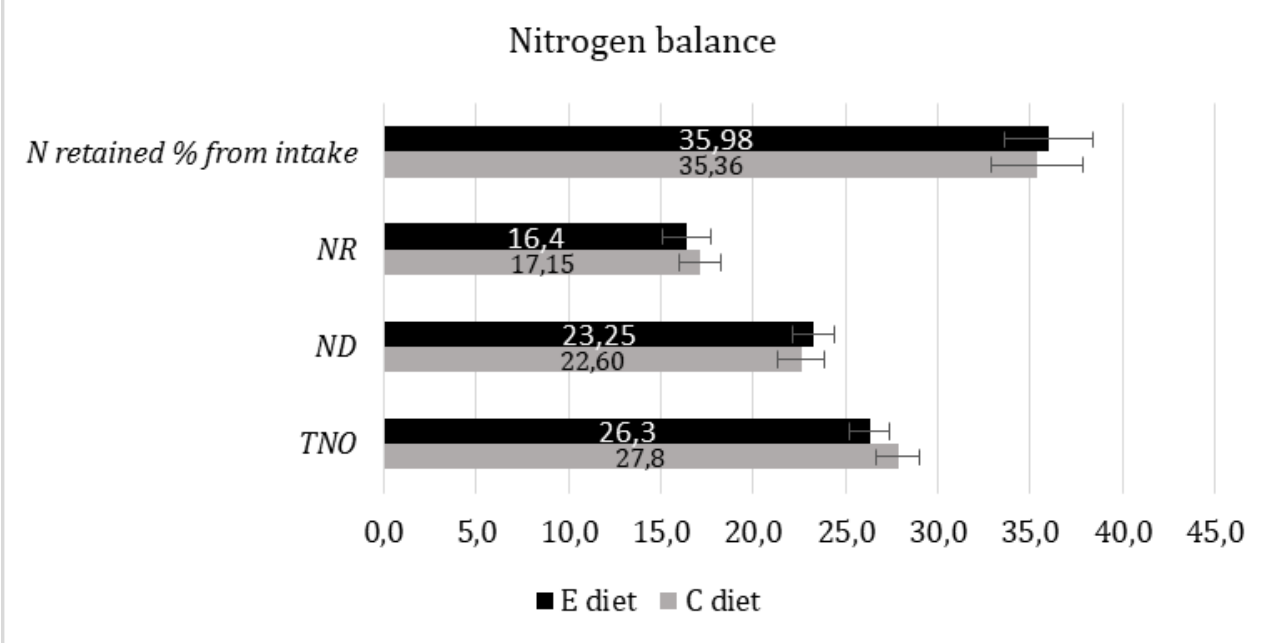

Figure 6. $\mathrm{N}$ metabolism in (g/head/day) pigs fed differently. Abbreviation: TNO = total $\mathrm{N}$ output; $\mathrm{NR}=\mathrm{N}$ retained; $\mathrm{ND}=\mathrm{N}$ digested

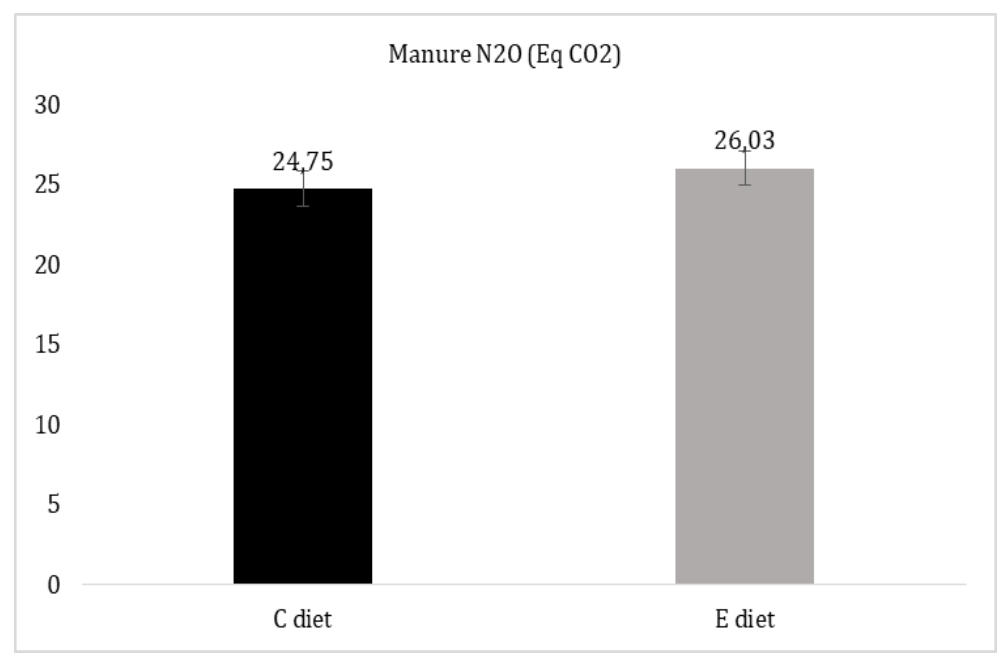

Figure 7. The concentration of $\mathrm{N}_{2} \mathrm{O}$ (g/head/day, Eq. $\mathrm{CO}_{2}$ ) predicted in the pigs' manure fed differently

In this study, the concentration of $\mathrm{N}_{2} \mathrm{O}$ expressed in $\mathrm{Eq}-\mathrm{CO}_{2}$ recorded a decline by $5 \%$ in animals fed MxG mixture. The data obtained in our bioassay are closed by that noticed by Dong et al. (2007), Li et al. (2011), Ngwabie et al. (2011) quote by Philippe and Nicks (2014). 


\section{CONCLUSION}

MxG cakes increase dietary fibre levels. Compared to the classic SFM, the MxG mixture cause a slight performances decline. TNO from pigs given MxG mixture is reduced, possibly due to the higher fibre level and its fractions. The same trend was observed in N20, which decreases by $5 \%$ in fibre-rich diet-fed animals. Based on these results, we conclude that the inclusion of a 15\% MxG mixture in pigs diets, although with reduced growth parameters, is a valuable nutritional solution that contributes to lowering $\mathrm{N}_{2} \mathrm{O}$ and nitrogen excretion. However, in terms of performance, SFM remains an ingredient with valuable potential.

\section{ACKNOWLEDGEMENTS}

This paper received financial support from the Ministry of Agriculture and Rural Development, Romania, through project ADER 9.1.4. /2019.

\section{REFERENCES}

Castrillón, N., González, V., Osorio, J.A., Montoya, A.P., and G. Correa. 2020. Assessment of the methane emission for different typologies of fattening swine facilities in the department of Antioquia Colombia. Agronomy Research 18(S2), 1189 1202, 2020. doi.org/10.15159/AR.20.108.

Dong, H., Zhu, Z., Shang, B., Kang, G., Zhu, H., Xin, H., 2007. Greenhouse gas emissions from swine barns of various production stages in suburban Beijing, China. Atmos. Environ. 41, 2391-2399.

Dourmad, J.Y., Garcia-Launay, F., Narcy, A. 2017. Pig nutrition: impact on nitrogen, phosphorus, $\mathrm{Cu}$ and $\mathrm{Zn}$ in pig manure and on emissions of ammonia, greenhouse gas and odours. Batfarm European Workshop Reconciling Livestock Management to the Environment. Mar 2013. Rennes. France. ffhal-01594359f. HAL Id: hal-01594359 https://hal.archives-ouvertes.fr/hal-01594359.

Dragomir, C., Habeanu, M., Gheorghe A. 2016. Rational Livestock Nutrition In Rural Areas. Chapter 3. Animal Feeding Systems in Europe.

Grossi, G, Goglio, P, Vitali, A., Williams, A.G. 2018. Livestock and climate change: impact of livestock on climate and mitigation strategies. Animal Frontiers, 9, (1), 69-76. doi.org/10.1093/af/vfy034.

Habeanu, M, Gheorghe A., Lefter N. A., Untea A., Idriceanu L., Ranta M. F.2020. Assessment of certain nitrogen metabolism indicators, enteric $\mathrm{CH} 4$ and $\mathrm{CO} 2$ emitted through manure related to different diets in barrow. Archiva Zootechnica. 23:2, 129-142. doi: 10.2478/azibna-2020-0018. 
Jarrett, S. and Ashworth, C.J. 2018. The role of dietary fibre in pig production, with a particular emphasis on reproduction. J Animal Sci Biotechnol. 9, 59.

Jørgensen, H., Prapaspongsa, T., Vu V.T.K., and Poulsen, H.D. 2013. Models to quantify excretion of dry matter, nitrogen, phosphorus and carbon in growing pigs fed regional diets. J Animal Sci Biotechnol 4, 42 (2013).

Lenerts, A., Popluga, D., and Naglis-Liepa, K. 2019. Benchmarking the GHG emissions intensities of crop and livestock-derived agricultural commodities produced in Latvia. Agronomy Research 17(5), 19421952. doi.org/10.15159/AR.19.148.

Li, W., Powers, W., Hill, G.M. 2011. Feeding distillers dried grains with solubles and organic trace mineral sources to swine and the resulting effect on gaseous emissions. J. Anim. Sci. 89, 3286-3299.

Millet, S., Aluwé, M.A., Broeke, V.D., Leen, F., De Boever, J., De Campeneere, S. 2018. Review: Pork production with maximal nitrogen efficiency. Animal. 12(5), 1060-1067. doi:10.1017/S1751731117002610.

Monteiro, D.O., Pinheiro, V.M.C., Mourão, J.LM., Rodriguez, M.A.M. 2010. Strategies for mitigation of nitrogen environmental impact from swine production. R. Bras. Zootec. 39, 317-325.

Moran, D. and Wall, E. 2011. Livestock production and greenhouse gas emissions: Defining the problem and specifying solutions. Animals Frontiers. 2011, Vol. 1, No. 1 doi:10.2527/af.2011-0012.

Ngwabie, N.M., Jeppsson, K.H., Nimmermark, S., Gustafsson, G., 2011. Effects of animal and climate parameters on gas emissions from a barn for fattening pigs. Appl. Eng. Agric. 27, 1027-1037.

Philippe, F-X. and Nicks, B. 2014 Review on greenhouse gas emissions from pig houses: Production of carbon dioxide, methane and nitrous oxide by animals and manure. Agr Ecosyst Environ. 199 e10-e25.

Wang, Y., Junyan, Z., Wang, G., Cai, S., Zeng, X. Qiao, S. 2018. Advances in lowprotein diets for swine. J Anim Sci Biotechnol. 9:60. https://doi.org/10.1186/s40104-018-0276-7.

The Intergovernmental Panel on Climate Change (IPCC, 2016, 2019) https://www.britannica.com/science/greenhouse-gas. 